\title{
Öğrenci, eğitmen ve hastaların bakış açısıyla diş hekimliği klinik eğitimi
}

\author{
Funda Akaltan(0000-0001-6744-6312) ${ }^{\alpha}$, İrem Öztürk(0000-0001-6585-7839) ${ }^{\alpha}$
}

Selcuk Dent J, 2019; 6: 134-147 (Doi: 10.15311/selcukdentj.485929)

Basvuru Tarihi: 20 Kasım 2018 Yayına Kabul Tarihi: 14 Aralık 2018

öz

Öğrenci, eğitmen ve hastaların bakış açısıyla diş hekimliği klinik eğitimi

Amaç: Öğrencilerin klinik ortamda öğrenme ve değerlendirmelerini etkileyen faktörler; ortam şartları, zaman kısıtlamaları ve yeterlikleri için gereken vakaları bulma sorunu olarak tanımlanmaktadır. Çalışmanın amacı; klinik eğitim ortamının öğrencilerin yanı sıra, klinik eğitmenler ve hastaların gözünden değerlendirilmesidir.

Gereç ve Yöntemler: Çalışma; Ankara Üniversitesi Diş Hekimliği Fakültesinde yürütülmüş ve 133 beşinci sınıf klinik öğrencisi, 107 klinik eğitmen ve 236 hasta yer almıştır.Klinik eğitim ortamının değerlendirilmesi için öğrenci, klinik eğitmen ve hastalarda kullanmak üzere 3 farklı anket geliştirilmiş; paydaşların klinik eğitim ortamındaki davranıs, duygu, beklenti ve kazanımları sorgulanmıştır. Anketlerin tümünde 5 düzeyli Likert skalası kullanılmıştır.Verilerin çözümlenmesinde SPSS 22.0 paket programı kullanılarak, ifadelere verilen yanıtların her düzeydeki yüzdeleri hesaplanmıştır.

Bulgular: Klinik eğitim ortamının öğrenciler ve eğitmenler için zorlu ve mücadele gerektiren özellikte olduğu görülmüştür. Öğrenciler; klinik eğitimin zor koşullarına rağmen, klinik beceri kazanma heveslerini ve eğitmenleri ile eğitim koşullarından beklentilerini açıkça dile getirmişlerdir. Klinik eğitmenler ise lisans klinik eğitim ortamında yer almaktan akademik olarak memnun olmakla birlikte, eğitimci olmadan önce deneyim kazanma intiyaçları olduğunu; gerek uygulama ve gerekse değerlendirme rehberleriyle daha güvenle çalışacaklarını bildirmişlerdir. Hastalar; tedavilerini gerçekleştiren öğrenciler ve eğitmenlerin davranışlarından memnuniyetlerini bildirmişler; eğitmenlerin gözetim ve değerlendirme yaparken hümanistik eğitim davranışları olarak bilinen ifadelere katıımlarını farklı düzeylerde açıkça ifade etmişlerdir.

Sonuç: Eğitim planlamaları yapılırken, öğretimin sadece öğretim üyeleri değil, diğer paydaşlar tarafından da değerlendirilmesi çok kıymetlidir. Eğitmen davranışları açısından öğrenci ve klinik eğitmenler arasında bazı uyumsuz yanıtlar alınmış olsa da, bulgular klinik eğitimde yaşanan sorunlar ile katılımcıların davranış, duygu, beklenti ve kazanımları konusunda fikir vermektedir.

\section{ANAHTAR KELIMELER}

Diş hekimliği, eğitim, öğrenciler, öğrenme

Diş hekimliği eğitiminin başarısı için öğrenciler, fakülte ve müfredat ögeleri üzerinde durmak ve bu konulardaki sorunlara çözüm önerileri getirmek kaçınılmazdır. ${ }^{1}$ Klinik eğitimde rol alan paydaşlar; başta öğrenciler ve eğitmenler

\section{ABSTRACT}

Dental clinical teaching: Perceptions of students, teachers and patients

Background: The aim of the present study was to evaluate the dental clinical teaching environment from the perspective of students, clinical teachers and the patients.

Methods: The study was conducted on 133 fifth grade students, 107 clinical teachers and 236 patients. For the evaluation of the clinical teaching environment; 3 different questionnaires were developed and graded using 5-point Likert scale. Data was analysed by using SPSS 22.0 package program and the the percentages of the responses were calculated.

Results: Clinical teaching environment showed various challenging factors not only for students but also for clinical teachers. Students clearly expressed that they were interested to achieve their clinical competence despite hard clinical teaching environment and they also defined their expectations from their teachers and clinical learning settings. The clinical teachers mentioned that they were academically satisfied to be involved in the undergraduate clinical education environment. However they stated that they needed to gain experience before becoming an educator and they would work more confidently with the presence of learning guides for clinical practice and evaluation. Patients stated their satisfactions about the behaviors of the students and teachers whom performed their treatment. However they expressed their responses about the the educators' teaching behaviors known as humanistic approach with different level of aggrements.

Conclusion: During the education planning, it is very valuable that education should not be evaluated only by faculty members. Results of the study demonstrated critical points about the behaviors, emotions, expectations and acquisitions of the participants.

\section{KEYWORDS}

Dental, education, students, learning

olmak üzere, yardımcı eğitmenler, yardımc personel ve hastalardır. Paydaşlar arasındaki doğru iletişim; eğitim için elverişli bir ortam sağlar. 
Klinik ortam; yeterli ve bağımsız klinik pratiği sergileyebilecek mezunların eğitimi için esastır. ${ }^{2}$ Klinik ortamın kullanımı; öğrencilerin deneyim ve uygulama yapma hızlarını arttırmaları için uzun süre uygulama yapmalarına fırsat veren ve öğrencinin öğrenim çıktılarının değerlendirilmesi için değerli bir yöntemdir.,3 Klinik öğretim ve öğrenme; diş hekimliği öğrencilerinin bağımsı klinik uygulamalarını yapabilme ve yetkin olarak toplumun ağız sağlığını oluşturabilme yeterlikleri için son derece önemlidir. Bu süreç sadece öğrenciler için değil, klinik eğitmenler için de zorluklarla doludur. ${ }^{5}$

Öğrencilerin öğrenme süreci; hastalar, klinik eğitmenler, yardımcı personel ve akranlarıla olan iletişimleri ile farklı klinik uygulamaları yansıtma deneyimleri gibi faktörlerden büyük ölçüde etkilenir. ${ }^{6}$ Klinikte güvenli ve etkili bir öğretimin oluşturulması için iyi derecede gözetmen denetimi ve iletişiminin olması gerekir. $^{7}$ ìyi eğitmen; bilgi ve becerilerini başarıyla aktarabilen ve öğrencilerin bilgi, beceri, tutum ve davranışlarında uygun değişiklikleri yapabilen kişi olarak tanımlanır. ${ }^{8}$ Klinik eğitmenlik ise; öğrencileri klinik uygulamalarını destekleyecek farklı seviyelerdeki bilgi ve tecrübeyle eğitmeleri beklendiğinden, daha zorlu bir görevdir. İyi klinik eğitmenlerin; öğrencilere rehber olma; öğretme ve öğrenmeyi destekleme; hastalar ve toplumların yararı için klinik uygulamalarda bilgi, iletişim, teknik beceriler, davranışlar ve tutumlarda uygun değişiklikleri başlatabilmede hünerli olmaları gerekir. ${ }^{5}$ Klinik öğrencilerinin yeni şeyleri tecrübe etmesi ve aynı zamanda etkili klinik öğretim sağlamak için iyi bir eğitim ortamı oluşturmak ve desteklemek; klinik gözetmenlerinin görevidir. ${ }^{9}$

Graffam $^{10}$; klinik eğitmenler tarafından uygulanan öğretim yaklaşımını değerlendiren uygun bir modelin olmadığını bildirmiş; yeterli spesifik öğretme modelinin, klinik eğitmenlerin görevlerini yerine getirmeleri için rehber olabileceğini ileri sürmüştür. Kavramsal çıraklık eğitim modeli (cognitive apprenticeship model); "düşünmeyi yüzeye çıkararak, görünür hale getirmek" tir. Bu yaklaşım; öğrencilerin denetim altındayken klinik uygulamaları gözleme, uygulama ve başarmalarını kolaylaştırabilir. ${ }^{11}$ Öğrencilerin kavramsal ve kavramsal olmayan becerilerini elde etmeleri için planlanan 6 öğretim alanından oluşan kavramsal çıraklık modeli; modelleme (modelling), yetiştirme (coaching), destek oluşturma (scaffolding), bir araya getirme (articulation), yansıma-doğaçlama (reflection) ve araştırma (exploration) olarak tanımlanmıştır. ${ }^{12} \mathrm{Bu}$ model; klinik öğretimde geri bildirim, kendini değerlendirme ve fakülte gelişimi için kullanışlı bir uygulama olarak önerilir; öğrencilerin bilgi ve klinik uygulama becerilerini nasıl birleştirdiklerini değerlendirir.

Öğrencilerin öğretimi değerlendirmesi; Birleşik Devletler'de ilk olarak 1920'de kullanılmaya başlanmış; ancak 1970'lerde yaygınlaşmıştır. ${ }^{13}$ Bunların kullanım amacl; eğitmenlere öğretimleri konusunda ve kişisel kararlarını yönetmelerinde geri bildirim vermek, öğrencileri dersleri ve eğitmenlerini tercih etmeleri aşamasında bilgilendirmek ve öğretim için yapılan araştırmalar için veri toplamaktır. ${ }^{14}$ Bununla birlikte eğitmenlerin işe alınması, terfisi ve kadrolarının belirlenmesi için bilgi toplamak ve öğretimin kalitesini arttırmak için de kullanılmıştır. ${ }^{15}$ Bu değerlendirmelerde öğretim ve öğrenmenin kalitesi hedeflenmelidir. ${ }^{16}$ Değerlendirmelerin nasıl yapılması gerektiğine yönelik yapılan araştırmalar; kapalı-uçlu sorulara ilaveten açıkuçlu öğrenci görüşlerinin alınmasını ${ }^{17}$ ve kağıt çıktılar yerine online olarak yapılmasını ${ }^{18-21}$ önermiştir. Web üzerinden yapılan değerlendirmeler daha az sayıda cevaplandırma ve düşük oranlarla sonuçlansa da daha detaylı öneriler içermektedir. ${ }^{21}$

Hastalar; diş hekimliği klinik eğitiminin önemli bir paydaşıdır ve kendilerini, kendi durumlarını ortaya koyabilen uzmanlar olarak düşündüklerinden, tıp ve diş hekimliği öğrencilerinin yetiştirilmesinde emeği geçen önemli kişiler olarak da görürler. ${ }^{22}$ Uzun yıllardan beri, eğitimciler ve öğrenciler de hastaların tıp eğitiminde eğitmen olmaları konusunda ciddi destek vermekte ve standardize hastalar; eğitimde önemli etkiye sahip olmaktadır. ${ }^{23}$ Standardize hastaların kullanımı; öğrencilerin klinik becerileri öğrenebilmeleri ve uygulama yapabilmeleri, hem bu amaçla eğitilmiş olan hastalar hem de eğitmenlerden geri bildirim almak için güvenli ve kontrollü ortamların oluşturulmasına imkan sağlar. ${ }^{24}$

Çalışmanın amacı; klinik eğitim ortamının öğrencilerin yanı sıra, klinik eğitmenler ve hastaların gözünden değerlendirilmesidir.

\section{GEREÇ VE YÖNTEM}

Çalışma öncesinde, Ankara Üniversitesi Diş Hekimliği Fakültesi Klinik Araştırmalar Etik Kurulu'ndan etik onay alınmıştır.

Çalışma Ankara Üniversitesi Diş Hekimliği Fakültesinde yürütülmüş; 133 beşinci sınıf klinik öğrencisi, 107 klinik eğitmen (klinik eğitimde en az 1 yıl süreyle görev almış uzman, araştırma görevlisi, uzmanlık ve doktora öğrencisi) ile 236 hasta (beşinci sınıf klinik öğrencilerine tedavi yaptırmış) yer almıştır.

Stalmeijer ve ark.'nın ${ }^{12}$; klinik uygulamalarda eğitmenin değerlendirilmesi için oluşturduğu "kavramsal çıraklık eğitim modeli" ve çalışmamızın ilk kısmında yer alan nitel çalışma sonuçları dikkate alınarak; öğrenci, eğitmen ve hasta için birer klinik eğitim ölçeği oluşturulmuştur.

Klinik eğitim ortamındaki paydaşların davranış, duygu, düşünce ve bakış açısını bulunduğu ortam içinde ve 
çok yönlü olarak anlamaya çalışmak için; çalışmanın ilk aşamasında nitel bir çalışma yürütülmüş; klinik eğitmenler, öğrenciler, yardımcı personel ve hastalarla görüşmeler yapılmıştır. Paydaşların klinik eğitimde kendi beklenti, duygu ve davranışlarını içeren açık uçlu sorular hazırlanmış ve cevaplardan elde edilen görüşler anket ifadeleri haline dönüştürülmüştür. Klinik eğitmenlerin değerlendirilmesinde kullanılan ifadeler için Stalmeijer ve ark.'nın ${ }^{12}$ alan ve tanımlamaları modifiye edilerek kullanılmıştır. Alanlar ve eğitmenlerin davranış tanımlamaları ${ }^{6}$ Tablo 1'de gösterilmektedir.

Tablo 1.

\section{Eğitmen davranışlarının değerlendirilmesinde kullanılan alan, tanımlayıcı davranışları ${ }^{6}$ (Tanımlayıcı davranışların; Tablo 4'te yer alan eğitmen davranışlarına denk gelen ifade numaraları parantez içinde belirtilmiştir)}

\begin{tabular}{|l|l|}
\hline Alan & Tanımlayıcı davranış ve ifade numaraları \\
\hline Model oluşturma & $\begin{array}{l}\text { Öğrencilere demonstrasyon yaparken kararlarını } \\
\text { ve gerekçelerini açıklayan (9) }\end{array}$ \\
\hline Yetiştirme & $\begin{array}{l}\text { Öğrencileri; uygulama yaparlarken gözlemleyen } \\
\text { ve işlem süresince geri bildirim yapan (10) }\end{array}$ \\
\hline Destek verme & $\begin{array}{l}\text { Öğrencilere; bilgi ve beceri düzeylerine göre } \\
\text { destek oluşturan (11, 12) }\end{array}$ \\
\hline Bir araya getirme & $\begin{array}{l}\text { Öğrencileri; bilgi ve nedensellikleri bir araya } \\
\text { getirmeleri için teşfik eden (9, 13,14) }\end{array}$ \\
\hline Doğaçlama oluşturma & $\begin{array}{l}\text { Öğrencileri; güçlü ve zayıf yönlerini geliştirmeleri } \\
\text { için teşfik eden (12, 15,16) }\end{array}$ \\
\hline
\end{tabular}

Klinik eğitim ortamının değerlendirilmesi için öğrenci, eğitmen ve hastalarda kullanmak üzere 3 farklı anket geliştirilmiştir. Klinik eğitim anketlerinde; (1) öğrencinin eğitim sürecindeki duygu ve davranışları ile klinik eğitmen davranışları, (2) klinik eğitmenin eğitim sürecindeki duygu, davranış, beklenti ve kazanımları (3) hastanın tedavi sürecinde öğrenci ve eğitmenlerde gözlemledikleri davranışları yer almaktadır. Anketlerin tümünde 5 düzeyli Likert skalası kullanılmıştır (hiç katılmıyorum-Hiç, katılmıyorum-K-, kısmen katılıyorum-KK, katılıorum-K+, tamamen katılıorum-TK). Anketler katılımcılara uygulanmadan önce, anlaşılır olması yönünden her biri küçük gruplarda denenmiş ve gereken düzenlemeler yapılmıştır.

Anketler net sözlü ve yazılı açıklamalar yapılarak, eğitim-öğretim dönemi sonunda katılımcılara uygulanmıştır. Tüm katılımcılar çalışmaya gönüllü olarak katılmış ve formlarda isim kullanılmamıştır.

Verilerin çözümlenmesinde SPSS 22.0 paket programı kullanılarak, ifadelere verilen yanıtların her

\section{BULGULAR}

Çalışmaya katılan öğrenciler, klinik eğitmenler ve hastaların klinik eğitim ortamı ile ilgili ifadelere vermiş oldukları yanıtlar yüzdeler üzerinden yorumlanmıştır.

Klinik eğitimde beceri kazanmak için çalıştıklarını K+ ve TK seviyelerinde belirten öğrenci oranı \% 90'ın üzerindedir (Tablo 2).

Tablo 2.

Öğrencilerin klinik eğitim sürecinde davranışları, duyguları ve beklentilerine yönelik yanıtlarının dağılımı (\%)

\begin{tabular}{|c|c|c|c|c|c|}
\hline \multirow{2}{*}{ Klinik eğitim sürecinde; } & \multicolumn{5}{|c|}{ Katılma Düzeyi } \\
\hline & Hiç & K- & KK & $\mathrm{K}+$ & TK \\
\hline $\begin{array}{l}\text { 1. Mesleğin gerektirdiği becerileri kazanmak için } \\
\text { çalışırım. }\end{array}$ & 1 & 2 & 5 & 40 & 52 \\
\hline $\begin{array}{l}\text { 2. Hastaya zarar vereceğim korkusuyla } \\
\text { kaygılanırım. }\end{array}$ & 3 & 3 & 16 & 43 & 35 \\
\hline $\begin{array}{l}\text { 3. Uygulamalarda hata yapacağım korkusu } \\
\text { yaşarım. }\end{array}$ & 2 & 7 & 40 & 37 & 14 \\
\hline 4. Kendimi hekim gibi hissederim. & 2 & 1 & 23 & 48 & 26 \\
\hline 5. İlgili ve meraklı davranırım. & 1 & 2 & 18 & 51 & 28 \\
\hline $\begin{array}{l}\text { 6. Uygulama öncesi teorik bilgilerimi gözden } \\
\text { geçiririm. }\end{array}$ & 4 & 9 & 36 & 41 & 10 \\
\hline 7. Kliniğin kurallarına uyarım. & & 1 & 18 & 61 & 20 \\
\hline 8. Etik kurallara uyarım. & & 1 & 12 & 52 & 35 \\
\hline 9. Sterilizasyon ve hijyen kurallarına uyarım. & & & 9 & 47 & 44 \\
\hline 10. Malzemeleri tasarruflu kullanırım. & 1 & 5 & 38 & 38 & 18 \\
\hline 11. El aletlerini işe uygun şekilde kullanırım. & & 1 & 17 & 59 & 23 \\
\hline 12. Gereken el aletlerimi yanımda bulundururum. & 1 & 2 & 22 & 56 & 19 \\
\hline $\begin{array}{l}\text { 13. Değerlendirme ölçütlerine dikkat ederek işi } \\
\text { tamamlarım. }\end{array}$ & 1 & 2 & 20 & 60 & 17 \\
\hline $\begin{array}{l}\text { 14. Uygulamaları acele etmeden, olması } \\
\text { gerektiği gibi tamamlarım. }\end{array}$ & 2 & 7 & 33 & 43 & 15 \\
\hline 15. Uygulamaları sakin şekilde yaparım. & 2 & 7 & 39 & 37 & 15 \\
\hline $\begin{array}{l}\text { 16. Teorik bilgilerimle klinik uygulamaları bir } \\
\text { araya getiririm. }\end{array}$ & & 2 & 24 & 60 & 14 \\
\hline $\begin{array}{l}\text { 17. Öğrenmemin iyileşmesi için, gerekirse klinik } \\
\text { uygulamayı tekrarlarım. }\end{array}$ & 2 & 8 & 38 & 38 & 14 \\
\hline $\begin{array}{l}\text { 18. Hastayı tedavi basamakları konusunda basit } \\
\text { şekilde bilgilendiririm. }\end{array}$ & & 2 & 11 & 57 & 30 \\
\hline $\begin{array}{l}\text { 19. Hastayı komplikasyonlar konusunda } \\
\text { bilgilendiririm. }\end{array}$ & & 2 & 14 & 55 & 29 \\
\hline $\begin{array}{l}\text { 20. Eğitmen gözetiminde çalışırken kendimi } \\
\text { güvende hissederim. }\end{array}$ & 2 & 2 & 17 & 54 & 25 \\
\hline
\end{tabular}

Öğrenciler; klinik eğitim ortamında büyük oranda ilgili ve meraklı davrandıklarını (\% $51 \mathrm{~K}+$ ve \% $28 \mathrm{TK})$, kendilerini hekim gibi hissettiklerini (\% $48 \mathrm{~K}+$ ve $\% 26 \mathrm{TK}$ ); ancak yine yüksek oranlarda hastaya zarar verme korkusu yaşadıklarını (\% $43 \mathrm{~K}+$ ve \% $35 \mathrm{TK}$ ) ve klinik uygulamalarda hata yapma korkusuyla kaygılandıklarını (\% $37 \mathrm{~K}+$ ve \% 14 TK) bildirmişlerdir. 
Klinik ortam açısından bakıldığında; öğrencilerin büyük oranda klinik kurallarına uyduklarını (\% 61 $\mathrm{K}+$ ve \% $20 \mathrm{TK})$, etik kurallara dikkat ettiklerini (\% $52 \mathrm{~K}+$ ve \% $35 \mathrm{TK}$ ), sterilizasyon ve hijyen kurallarını sağladıklarını (\% $47 \mathrm{~K}+$ ve \% $44 \mathrm{TK}$ ), el aletlerini işe uygun şekilde kullandıklarını (\% $59 \mathrm{~K}+$ ve \% $23 \mathrm{TK}$ ), gereken el aletlerini yanlarında bulundurduklarını (\% $56 \mathrm{~K}+$ ve \% 19 TK); ancak malzemeleri tasarruflu kullanmada fazla başarılı olmadıklarını (\% $38 \mathrm{~K}+$ ve \% $18 \mathrm{TK}$ ) bildirmişlerdir.

Klinik uygulamaları gerçekleştirmek açısından bakıldığında; öğrencilerin sadece yarısı; klinik uygulama öncesi teorik bilgilerini gözden geçirdiklerini (\% $41 \mathrm{~K}+$ ve \% 10 TK), \% 36'sı ise bu davranışı kısmen sergilediklerini ifade etmişlerdir. Öğrencilerin büyük çoğunluğu (\% 60 K+ ve \% 17 TK) değerlendirme ölçütlerine dikkat ederek işleri tamamladıklarını bildirmişlerdir; ancak "uygulamaları acele etmeden, olması gerektiği gibi ve sakin şekilde yaparım" ifadelerini $\mathrm{K}+$ ve TK düzeylerinde yanitlayan öğrencilerin oranı daha düşüktür (\% 60).

"Teorik bilgi ve klinik uygulamalarımı bir araya getiririm" ifadesini öğrencilerin çoğu (\% 74) K+ ve TK düzeylerinde yanıtlamıştır. "Öğrenmemin iyileşmesi için, gerekirse klinik uygulamayı tekrarlarım" ifadesini $\mathrm{K}+$ ve TK düzeylerinde yanıtlayan öğrencilerin toplam oranı \% 52'dir. Öğrencilerin eğitmen gözetiminde çalışırken kendilerini güvende hissettiklerine katılımları aynı düzeylerin toplamında \% 76'ya ulaşmıştır.

Öğrencilerin hastalarını tedavi öncesinde bilgilendirmeleri açısından bir değerlendirme yapıldığında, "hastayı tedavi basamakları ve komplikasyonlar konusunda basit şekilde bilgilendiririm" ifadelerini $\mathrm{K}+$ ve TK düzeyleri toplamında yanıtlayan öğrencilerin oranları; sırasıyla \% 87 ve \% 84'dür.

Öğrenciler; K+ ve TK düzeyleri toplamında, klinik eğitmenlerin sadece, kliniğin çalışma düzeni konusunda bilgilendirme yapmasına \% 57 ile en yüksek yanıtı vermişler; geriye kalan tüm klinik eğitmen davranışlarındaki yanıtları, bu düzeyler toplamında yarının altında kalmıştır. Eğitmenlerin etik kurallar, sterilizasyon ve hijyen kuralları, malzemeleri doğru kullanma, el aletlerini uygun kullanma, ünit kullanımı, hastayı bilgilendirme, sürece ve ürüne ait değerlendirme ölçütleri ile ilgili bilgilendirmeleri yapma ifadelerine öğrencilerin verdikleri yanıtların TK düzeyinin çok düşük olduğu gözlenmiştir (\% 213) (Tablo 3).
Tablo 3.

\section{Öğrencilerin klinik eğitim sürecinde eğitmenin davranışlarına yönelik yanıtlarının dağılımı (\%)}

\begin{tabular}{|c|c|c|c|c|c|}
\hline \multirow{2}{*}{ Klinik eğitim sürecinde eğitmen; } & \multicolumn{5}{|c|}{ Katılma Düzeyi } \\
\hline & Hiç & K- & KK & $\mathbf{K}+$ & TK \\
\hline 1. Kliniğin çalışma düzeni konusunda bilgilendirme yapar. & 5 & 10 & 28 & 45 & 12 \\
\hline 2. Etik kurallar konusunda bilgilendirme yapar. & 5 & 14 & 41 & 34 & 6 \\
\hline $\begin{array}{l}\text { 3. Sterilizasyon ve hijyen kuralları konusunda } \\
\text { bilgilendirme yapar. }\end{array}$ & 4 & 18 & 29 & 40 & 9 \\
\hline 4. Malzemeleri kullanma konusunda bilgilendirme yapar. & 6 & 16 & 34 & 31 & 13 \\
\hline $\begin{array}{l}\text { 5. El aletlerini uygun şekilde kullanma konusunda } \\
\text { bilgilendirme yapar. }\end{array}$ & 8 & 20 & 33 & 32 & 7 \\
\hline 6. Hastayı bilgilendirme konusunda bilgilendirme yapar. & 5 & 14 & 41 & 34 & 6 \\
\hline 7. Hastayla iletişim konusunda bilgilendirme yapar. & 7 & 20 & 35 & 30 & 8 \\
\hline 8. Ünit kullanımı konusunda bilgilendirme yapar. & 10 & 21 & 35 & 26 & 8 \\
\hline $\begin{array}{l}\text { 9. Sürece ait değerlendirme ölçütleri konusunda } \\
\text { bilgilendirme yapar. }\end{array}$ & 7 & 20 & 32 & 33 & 8 \\
\hline $\begin{array}{l}\text { 10. Ürüne ait değerlendirme ölçütleri konusunda } \\
\text { bilgilendirme yapar. }\end{array}$ & 9 & 22 & 32 & 31 & 6 \\
\hline 11. Farklı uygulamalardan önce demonstrasyon yapar. & 14 & 22 & 35 & 22 & 7 \\
\hline $\begin{array}{l}\text { 12. Teorik bilgilerle uyumlu klinik uygulamalar yapmamızı } \\
\text { sağlar. }\end{array}$ & 11 & 14 & 35 & 35 & 5 \\
\hline $\begin{array}{l}\text { 13. Uygulamaların çalışma süresine uygun sayıda } \\
\text { olmasını sağlar. }\end{array}$ & 20 & 24 & 28 & 26 & 2 \\
\hline $\begin{array}{l}\text { 14. Uygulamaların eğitim seviyesine uygun nitelikte } \\
\text { olmasını sağlar. }\end{array}$ & 8 & 17 & 39 & 32 & 4 \\
\hline 15. Hastayla iletişim sorunu yaşamama müdahale eder. & 13 & 16 & 38 & 26 & 7 \\
\hline 16. Kendi deneyimlerinden faydalanmamı sağlar. & 9 & 14 & 40 & 28 & 9 \\
\hline $\begin{array}{l}\text { 17. Hatamı düzeltemeye yönelik uygulama yapmamı } \\
\text { sağlar. }\end{array}$ & 11 & 17 & 32 & 32 & 8 \\
\hline $\begin{array}{l}\text { 18. İhtiyaç duyduğumda uygulamamı gerçekleştirmeme } \\
\text { yardımcı olur. }\end{array}$ & 11 & 17 & 36 & 28 & 8 \\
\hline 19. Hatalarım karşısında sabırlı davranır. & 14 & 23 & 35 & 23 & 5 \\
\hline $\begin{array}{l}\text { 20. Hatalı uygulamalarımı, hastanın duymayacağı şekilde } \\
\text { söyler. }\end{array}$ & 14 & 20 & 26 & 32 & 8 \\
\hline 21. Olumlu eleştirilerini hastanın duyacağı şekilde söyler. & 8 & 15 & 32 & 32 & 13 \\
\hline
\end{tabular}

Klinik eğitmenlerin "hastayla iletişim konusunda önceden bilgilendirme yapması" ve "hastayla iletişim sorunu yaşandığında müdahale etmesi" davranışlarına yanıtları; K+ ve TK düzeyleri toplamında sırasıyla \% 38 ve \% 32'dir.

Klinik uygulamaların eğitim seviyesine ve çalışma sürelerine uygun olmasına yönelik öğrenci yanıtları; yine $\mathrm{K}+$ ve TK düzeyleri toplamında sırasıyla \% 36 ve \% 28'dir.

Uygulamalar sürecindeki klinik eğitmen davranışlarına öğrencilerin $\mathrm{K}+$ ve TK düzeyleri toplamındaki yanıtları; klinikte farklı uygulamalardan önce demonstrasyon yapmasına \% 29, kendi deneyimlerinden öğrencinin faydalanmasını sağlamasına $\% 37$, hatasını düzeltmeye yönelik uygulama yapmasına \% 40, intiyaç duyduğunda uygulamayı yapmasına yardımcı olmasına $\% 36$, hataları karşısında sabırlı davranmasına \% 28, hatalı uygulamaları hastanın duymayacağı şekilde söylemesine \% 40 ve olumlu eleştirilerini hastanın duyacağı şekilde söylemesine \% 45 gibi düşük oranlarda kalmıştır. 
Klinik eğitmenlerin lisans klinik eğitim sürecinde kendi davranış, duygu ve beklentileri değerlendirildiğinde K+ ve TK düzeyleri toplamında; "akademik anlamda mutlu olurum" \% 73, "öğrencilerle iletişim kurmaktan mutlu olurum" \% 88, "klinik becerilerimi geliştiririm" \% 74, "karar verme becerimi geliştiririm" \% 90, "tedavi uygulamalarımdaki hatalarımı görürüm" $\% 68$ oranlarında yanıt bulmuştur (Tablo 4).

Klinik eğitmenlerin klinik çalışma düzenine yönelik düşünce ve davranışlarına bakıldığında $K+$ ve $T K$ düzeyleri toplamında; "çalışma kurallarına ilişkin yazıı talimatlar olduğunda daha güvenle çalışırım" $\%$ 80, "deneyim kazandıktan sonra eğitici olarak görev alsaydım diye düşünürüm" \% 71 oranlarında yanıtlanmıştır.

Öğrencilerin klinik eğitiminde kendi davranışlarına yönelik vermiş oldukları yanıtlar yine $K+$ ve TK düzeyleri toplamında yoğunlaşmış; öğrencilere, çalışma düzeniyle ilgili bilgilendirme yaptıklarını (\% 89), demonstrasyon yaptıklarını (\% 87), öğrenciyi gözetimde tutup (\% 86), gerektiğinde müdahale ettiklerini (\% 92), yaptığı hatayı anlatıp düzeltmesini beklediklerini (\% 96), klinik uygulama süreci ve ürüne ait değerlendirme ölçütlerini önceden verdiklerini (\% 70 - diğerlerine göre daha düşük), yaptığı hatayı incitmeden söylediklerini (\% 88) ve olumlu eleştirilerini hastanın duyacağı şekilde söylediklerini (\% 80) bildirmişlerdir. Klinik eğitmenler; kendileri hakkındaki geri bildirimlerde olumlu öğretim davranışları sergilediklerini ifade etmişlerdir.

Hastaların yanıtları da genellikle $\mathrm{K}+$ ve TK düzeylerinde yoğunlaşmış; genel olarak öğrencilerin tutum ve davranışlarından memnun kaldıklarını ifade etmişlerdir. Öğrencinin; güler yüzle karşıladığını (\% 90), görüntüsünün güven verici (\% 89) ve temiz (\% 91) olduğunu ifade etmişlerdir (Tablo 5).

Tedavi tercihi konusunda görüş alma (\% 78), tedavi boyunca bilgilendirme (\% 80), aksilikler konusunda bilgilendirme (\% 75) ve ağrı hissedeceğini önceden bildirme (\% 77) davranışlarına, yüksek oranlarda ve $\mathrm{K}+$ ve TK düzeylerinde katılmışlardır.

Öğrencilerin; tedavi boyunca düzenli (\% 76) ve sakin (\% 88), acemi davranmadan (\% 65) ve gerektiğinde teselli ederek (\% 76) çalıştığını yanıtlayan hasta oranları K+ ve TK düzeylerinde oldukça yüksektir. Öğrencilerin; tedavi kararlarında kararsı kalma davranışı hastalara sorulduğunda; tüm katıım düzeylerine verilen yanıtlar dengeli olurken, en yüksek yanıt $H$ ilç düzeyinde \% 32 ile görülmüştür.
Hastalar; öğrencilerin çalışıken eğitmen gözetiminde olduklarını K+ ve TK düzeylerinde $\% 67$ oranında yanıtlamışlardır. Öğrencilerin kararları için eğitmenlerinden onay aldıklarını $\mathrm{K}+$ ve TK düzeylerinde yanıtlayan hastaların oranı \% $77^{\prime}$ 'dir.

Hastalar; K+ ve TK düzeyleri toplamında, "hoca, hekimin hatalarını duyacağım şekilde söyledi" ifadesine \% 39 ; "hoca, hekimin yaptıklarını beğendiğini duyacağım şekilde söyledi" ifadesine $\% 54$ oranında katımışlardır.

\section{Tablo 4.}

Klinik eğitmenlerin klinik eğitim sürecinde kendi davranışları, duyguları, beklentileri ve kazanımları ile öğrencilere uyguladıkları öğretim davranışlarına yönelik yanıtlarının dağılımı (\%)

\begin{tabular}{|c|c|c|c|c|c|}
\hline \multirow{2}{*}{ Lisans klinik eğitimi verirken; } & \multicolumn{5}{|c|}{ Katılma Düzeyi } \\
\hline & Hiç & K- & KK & $\mathbf{K}+$ & TK \\
\hline 1. Akademik anlamda mutlu olurum. & & 7 & 20 & 40 & 33 \\
\hline 2. Öğrencilerle iletişim kurmaktan mutlu olurum. & 1 & 2 & 9 & 43 & 45 \\
\hline 3. Klinik becerilerimi geliştiririm. & & 6 & 20 & 34 & 40 \\
\hline 4. Karar verme becerimi geliştiririm. & & & 10 & 45 & 45 \\
\hline 5. Tedavi uygulamalarındaki hatalarımı görürüm. & 3 & 8 & 21 & 39 & 29 \\
\hline $\begin{array}{l}\text { 6. Çalışma kurallarına ilişkin yazılı talimatlar varsa } \\
\text { güvenle çalışırım. }\end{array}$ & 4 & 6 & 10 & 43 & 37 \\
\hline $\begin{array}{l}\text { 7. Deneyim kazanıp eğitici olarak görev alsaydım } \\
\text { diye düşünürüm. }\end{array}$ & 1 & 11 & 17 & 31 & 40 \\
\hline $\begin{array}{l}\text { 8. Çalışma düzeniyle ilgili öğrencime önceden } \\
\text { bilgilendirme yaparım. }\end{array}$ & 2 & 3 & 6 & 41 & 48 \\
\hline 9. Farklı tedavilerden önce demonstrasyon yaparım. & 2 & 2 & 9 & 45 & 42 \\
\hline 10. Öğrenciyi gözetimde tutarım. & 1 & 3 & 10 & 43 & 43 \\
\hline 11. Öğrenciye gerektiğinde müdahale ederim. & & & 8 & 40 & 52 \\
\hline $\begin{array}{l}\text { 12. Öğrenciye yaptığı hatayı anlatır, düzeltmesini } \\
\text { beklerim. }\end{array}$ & & 1 & 3 & 51 & 45 \\
\hline $\begin{array}{l}\text { 13. Sürece ait değerlendirme ölçütlerini eğitimden } \\
\text { önce öğrencilere veririm. }\end{array}$ & 2 & 2 & 26 & 45 & 25 \\
\hline $\begin{array}{l}\text { 14. Ürüne ait değerlendirme ölçütlerini eğitimden } \\
\text { önce öğrencilere veririm. }\end{array}$ & 2 & 3 & 26 & 45 & 25 \\
\hline $\begin{array}{l}\text { 15. Öğrenciye yaptığı hatayı onu incitmeden } \\
\text { söylerim. }\end{array}$ & & 1 & 12 & 39 & 48 \\
\hline $\begin{array}{l}\text { 16. Öğrenciyle ilgili olumlu eleştirimi hastasının } \\
\text { duyacağı şekilde söylerim. }\end{array}$ & 8 & 6 & 6 & 34 & 46 \\
\hline
\end{tabular}


Tablo 5.

\section{Hastaların klinik tedavilerinde klinik eğitim ortamına yönelik yanıtlarının dağılımı (\%)}

\begin{tabular}{|c|c|c|c|c|c|}
\hline \multirow{2}{*}{ Diş tedavimde; } & \multicolumn{5}{|c|}{ Katılma Düzeyi } \\
\hline & Hiç & K- & KK & $\mathbf{K}+$ & TK \\
\hline 1. Hekim beni güler yüzle karşıladı. & 1 & 2 & 7 & 43 & 47 \\
\hline 2. Hekimin görüntüsü güven vericiydi. & 1 & 2 & 8 & 37 & 52 \\
\hline 3. Hekim temiz görünümdeydi. & 2 & 1 & 6 & 40 & 51 \\
\hline $\begin{array}{l}\text { 4. Hekim tedavi tercihim konusunda } \\
\text { görüşümü aldı. }\end{array}$ & 3 & 5 & 14 & 39 & 39 \\
\hline 5. Hekim tedavim boyunca beni bilgilendirdi. & 2 & 2 & 16 & 33 & 47 \\
\hline $\begin{array}{l}\text { 6. Hekim tedavide karşılaşacağım aksilikler } \\
\text { konusunda bilgilendirdi. }\end{array}$ & 4 & 7 & 14 & 37 & 38 \\
\hline 7. Hekim ağrı hissedeceğimi önceden bildirdi. & 3 & 7 & 13 & 37 & 40 \\
\hline 8. Hekim tedavi boyunca düzenli çalıştı. & 1 & 3 & 10 & 34 & 52 \\
\hline 9. Hekim sakin bir şekilde çalıştı. & 1 & 2 & 9 & 39 & 49 \\
\hline $\begin{array}{l}\text { 10. Hekim endişelerimi gidermek için beni } \\
\text { teselli etti. }\end{array}$ & 4 & 5 & 15 & 38 & 38 \\
\hline 11. Hekim acemi davranış sergiledi. & 36 & 29 & 13 & 12 & 10 \\
\hline 12. Hekim hoca gözetimi altında çalıştı. & 6 & 7 & 20 & 35 & 32 \\
\hline 13. Hekim tedavi kararlarında kararsız kaldı. & 32 & 27 & 16 & 13 & 12 \\
\hline 14. Hekim kararları için hocadan onay aldı. & 4 & 6 & 13 & 43 & 34 \\
\hline $\begin{array}{l}\text { 15. Hekim zorlandığı durumlarda hocadan } \\
\text { yardım aldı. }\end{array}$ & 10 & 11 & 15 & 38 & 26 \\
\hline $\begin{array}{l}\text { 16. Hoca, hekimin hatalarını duyacağım } \\
\text { şekilde söyledi. }\end{array}$ & 22 & 22 & 17 & 22 & 17 \\
\hline $\begin{array}{l}\text { 17. Hoca, hekimin yaptıklarını beğendiğini } \\
\text { duyacağım şekilde söyledi. }\end{array}$ & 14 & 12 & 20 & 29 & 25 \\
\hline
\end{tabular}

\section{TARTIŞMA}

Ankara Üniversitesi Diş Hekimliği Fakültesi'ndeki klinik eğitmenler fakülte öğretim üyeleri, uzmanlar, araştırma görevlileri, uzmanlık öğrencileri ile doktora öğrencilerinden oluşmaktadır. Dördüncü ve beşinci sınıfta klinik eğitim gören öğrenci sayısı toplamı 400'ün üzerindedir. Öğrenciler 8 anabilim dalına ait kliniklerde önceden belirlenmiş klinik eğitim sürelerinde eğitim görür; öğretim üyeleri ve klinik eğitmenlerin (uzmanlar, araştırma görevlileri, uzmanlık öğrencileri ve doktora öğrencileri) gözetimi ve denetiminde, önceden belirlenmiş klinik uygulama görevlerini yerine getirir; gerek klinik eğitim dönemi ve gerekse dönem sonunda klinik becerilere ulaşmaları açısından değerlendirilirler. Fakülte kliniklerinin fiziksel, yardımcı personel ve ekipman özellikleri ile öğrenci sayısı ideal klinik eğitim koşullarını sergilememekle birlikte, kliniklere başvuran hasta sayısı; öğrencilerin klinik uygulama çeşitliğine ulaşmaları ve deneyim kazanmaları açısından avantaj yaratmaktadır.
Dünyadaki tüm tıp ve diş hekimliği okulları geleneksel olarak öğretim üyelerinin öğretim şekillerini sorgulamaktan ve uygulamalardaki hataları ortaya çıkarmaktan kaçınmıştır. ${ }^{1}$ Eğitimin geliştirilebilmesi, değişen öğrenci jenerasyonu ve çağdaş eğitim modellerine adapte edilebilmesi için eğitmenlerin eğitim işini birincil görevleri olarak algılamaları, karşılıklı etkileşimli öğretme yöntemleri hakkında eğitilmeleri ve farklı öğretme yöntemlerini bir arada kullanmaları gerekmektedir.

\section{Öğrencilerin öğretimi değerlendirmesi} uygulamasının öğrenciler ve fakülte üyeleri tarafından değerlendirildiği bir araştırmada ${ }^{13}$; son sınıf öğrencileri, diğer öğrencilere göre bu değerlendirmelerin daha az faydalı olduğunu belirtmişlerdir. Öğrencilerin öğretimi değerlendirdiği uygulamaların web-tabanlı ve kısa olması, açık-uçlu geribildirime izin vermesi, tüm sınıflara uygulanması ve her sınıfla ilgili spesifik durumları değerlendirmeye olanak sağlaması sonucu ortaya konulmuş; sınıf eğitimlerinin yanı sıra klinik eğitimde de uygulanması gerektiği vurgulanmış; daha önce yapılan değerlendirmeler sonucunda fakültelerde yapılan somut değişikliklerin mutlaka öğrencilere duyurulması gerektiği de rapor edilmiştir. ${ }^{13}$

Stalmeijer ve ark.'na ${ }^{12}$ göre, eğitmen açısından bakıldığında, etkili öğretim sağlamak için öğrencilerin yetiştirilmesinde en etkili yöntemleri seçmek ve oluşturmak gerekmektedir. Öğretim ve öğrenme aktiviteleri; eğitim sürecinin sonunda öğrencilerin uygun klinik becerileri elde etmesini hedeflediğinden, öğrencilerin algılarının dikkate alınması ve değerlendirilmesinin anlamlı olduğu bildirilmektedir6; böylece öğretimin iyileştirilmesi için klinik eğitmenlere yapıcı geri bildirim oluşturulacaktır. Bu tarz çalışmalardan elde edilen veriler ve yanıtlar fakülte eğitmenleriyle paylaşılacak ve hatta gelecekte klinik eğitimin etkinliğinin iyileştirilmesi için yapılacak değerlendirmelere bir ölçek oluşturmaya yol gösterecektir. ${ }^{6}$ Öğrencilerin yanıtlarını; öğrencilerin daha iyi öğrenmeleri için bir intiyaç olarak yorumlamak ve sonuçları gizlemek yerine, konunun muhataplarıyla paylaşmak gerekir.

Çalışmada; klinik öğretimin öğrenciler, klinik eğitmenler ve hastaların bakış açısılyla, eğitmen ve öğrencilerin davranışları, düşünceleri, beklentileri ve duyguları yönünden değerlendirilmesi amaçlanmıştır. Eğitmen olarak klinik eğitimde önemli paydaşlarımız olan yardımcı eğitmenler yer almıştır. Çalışmamız; klinik eğitim ortamını daha fazla tanımaya fırsat verecek betimsel bir araştırma olduğu için sonuçlar ilişkilendirilmemiş; nedenler 
üzerinde durulmamıştır. Kliniklerin fiziksel altyapısı, malzeme, temizlik, yardımcı personel gibi klinik ortam faktörleri de çalışma kapsamına alınmamıştır.

Özellikle öğretimi iyileştirmek ve derslerin geliştirilmesi amacıyla yapılan bu değerlendirmelerde yöntemler de araştırılmıştır. ${ }^{25}$ En çok kullanılan yöntem; eğitim ortamı için geliştirilen ifadelere öğrencilerin farklı katılım düzeylerindeki yanıtlarını değerlendirmektir. ${ }^{13} \mathrm{Bu}$ değerlendirmelerde yaşanan problemlerden bazıları; düşük cevap oranları ${ }^{26}$, cevap skalalarının subjektif oluşu $^{27}$ ve katılımcıların yaş, cinsiyet veya kültürel özellikleri yönüyle taraflı yanıtlama intimalleri ${ }^{28}$ olarak sayılabilir. Tarafsız olmasını desteklemek amacıyla, çalışmamızdaki değerlendirmeler; sadece öğrenciler değil, klinik eğitmen ve hastaların algıları da dikkate alınarak gerçekleştirilmiştir.

Klinik eğitimde beceri kazanmak için çalıştıklarını $\mathrm{K}+$ ve TK seviyelerinde belirten öğrenci oranı \% 90'ın üzerindedir ve dolayısıyla öğrenciler; bağımsız ve denetimsiz ortamdaki çalışmalarına geçmeden önce, klinik uygulamalarda yetkin olmayı amaçladıklarını açıkça belirtmişlerdir.

Öğrenciler; öğretimi değerlendirdikleri bir çalışmada6; klinik beceriler konusunda kendilerine güvenmediklerini, zamanı iyi kullanamadıklarını, klinik eğitime hazırlıksız geldiklerini, ilerlemelerinin yavaş olduğunu ve hatalarının farkında olduklarını ifade etmişlerdir. Çalışmamızda; klinik ve çalışma kurallarına uyduklarını \% 70'in üzerindeki oranlarda katılımla ifade eden öğrencilerimiz, malzemeleri tasarruflu kullanma konusunda başarılı olmadıklarının farkındadırlar.

Klinik eğitimde genellikle öğrencilerin temel bilgileriyle uygulama becerileri arasında entegrasyonu sağlayan bir öğrenme ortamı oluşturulur. ${ }^{29}$ Öğrenciler klinik eğitmenlerin rehberliğine daha fazla ihtiyaç duyduklarını ve teorik bilgiyle klinik uygulamaları entegre etmenin, hasta tedavisi için gelecekteki klinik uygulamaları gerçekleştirmelerinde kolaylık sağlayacağını ifade etmişlerdir. ${ }^{6}$ Çalışmamızda; öğrencilerin sadece yarısı klinik uygulama öncesinde teorik bilgilerini gözden geçirdiğini, \% 36'sı ise bunu kısmen yaptığını ifade etmiştir; oysa ki öğrenciler en fazla başarısızlık ve telaşı teorik bilgi eksikliği nedeniyle yaşarlar. Öğrenciler genellikle teorik bilgilerle klinik uygulamaları entegre etmede zorluk yaşadıklarından şikayet etseler de, çalışmamıza katılan öğrencilerin \% 74'ü bunu başarabildiklerini ifade etmişlerdir. Bununla birlikte öğrenciler; öğrenmeyi desteklemek için gerekirse klinik uygulamayı tekrarlamak yerine, daha az başarılı tedavileri göze almaktadırlar. Yetersiz süre; öğrencilerin ve eğitmenlerin rutin uygulamalar ve işlem sıralamalarını ihmal etmelerine, öğrenme senaryolarının avantajlarını ortaya koymadan tedavi yapmalarına ve işbirliği içindeaktif öğrenme yöntemlerini kullanmaları için zaman ayıramamalarına neden olmaktadır. ${ }^{30}$
Klinik eğitim ve değerlendirme; hastanın ihtiyaçlarını göz ardı edecek şekilde öğrenci gereksinimleriyle kuşatılabilir. Klinik ihtiyaçlar için hastaların kullanımı; uygun klinik davranış için gereken etik prensipleri tehlikeye düşürebilir ${ }^{31}$; çünkü çoğunlukla öğrenciler klinik uygulamaların gereksinimleri ve tamamlanması için baskı altında kalırlar. Çalışmamıza katılan öğrenciler; yüksek katılım oranlarıyla (\% $52 \mathrm{~K}+$ ve \% 35 TK), etik kurallara uygun olarak çalıştıklarını bildirmişlerdir.

Gözetmenin öğrenciyi eğitmesi ve hastaya zarar vermesini önlemesi gerekir. Eğitmen; hastanın intiyaçları, istekleri, değerleri ve beklentilerine öğrencinin saygı duymasını öğretmeli; öğrencileri klinik koşullar hakkında bilgilendirmelidir. ${ }^{31}$ Çalışmamızda öğrenciler; eğitmenlerin bu yöndeki davranışları ve bilgilendirmelerine düşük oranlarda katılım sergileyerek, eğitmenlerinden yeterli desteği almadıklarını ifade etmişlerdir. Klinik eğitmenlerin kendi eğitimleriyle ilgili sorumlulukları ve görevlerinin de olduğu düşünüldüğünde, özellikle eğitim yükü fazla olan anabilim dallarında çalışanlar açısından durum daha kritik olup, öğrencilerin eğitimini desteklemede yetersiz kalmaları; anlaşılabilir bir sorundur.

Diş hekimliği öğrencileri; yeterliklere veya klinik uygulamalara uygun hasta aramaları gerekliliği ve eğitim araçları olarak hastaların kullanımının yarattığı etik sorunları, anksiyetelerinin başlıca nedenleri olarak tanımlamışlardır. ${ }^{3}$ Öğrencinin öğrenim ihtiyaçları ve hastaya zarar vermeme çabasından dolayı gerilim oluşabilir. ${ }^{32}$ Çalışmamıza katılan öğrenciler de klinik eğitim ortamında büyük oranda ilgili ve meraklı davrandıklarını, kendilerini hekim gibi hissettiklerini; ancak hastaya zarar verme korkusu yaşadıklarını ve klinik uygulamalarda hata yapma korkusuyla kaygılandıklarını bildirmişlerdir.

Dental eğitmenler; öğretim görevleri farklı olan sınıflar, laboratuvarlar ve bazı ülkelerde fakülte dışındaki/toplum destekli klinikler gibi farklı ortamlarda klinik eğitim yaparlar. ${ }^{33-35}$ Tek bir eğitim ortamında bile, eğitmenlerin öğrencileri desteklemek için birkaç görevi üstlenmeleri gerekir. Küçük grup çalışmalarında, eğitmenler hem "öğrenimi kolaylaştırıcı" olarak öğrencilerin bir araya gelmesi ve grup içindeki tartışmalarını destekler hem de "bilgi üretici” olarak öğrencilerin tartışmalarını ilerletebilmelerine yardımcı olur. Eğitmenlerin genel kapsamdaki uzmanlığı; öğrencilerin bilgilerini iyileştirir ve yanlışlarını düzeltir. ${ }^{36}$

Öğretim görevleri; klinik ortamları içinde ve dışındaki öğrenim içeriklerini kapsar. Eğitmenlerin görevleri; bilgi üretmek, öğrenci öğrenimine gözetmenlik yapmak ve desteklemek, öğrencilerin bilgi ve yeterliklerini geliştirmelerine yardımcı olmak ve kolaylaştırmaktır. ${ }^{37}$ 
Uygulama becerilerinin direkt gözlenmesi (direct observation of procedural skills-DOPS) ve düzeltici geribildirim (corrective feedback) beceri eğitimini iyileştirmenin en önemli araçlarındandır. ${ }^{38} \mathrm{Bu}$ gözlem; periodontoloji ana bilim dalında klinik eğitim gören 15 lisans öğrencisine 4 fakülte öğretim üyesi tarafından uygulanmış; öğrencilerin ağız muayenesi, veri toplanması, periodontal değerlendirme, fırçalama tekniğinin gösterimi, detertraj ve ultrasonik detertraj becerileri değerlendirilmiştir. Öğrenciler bu uygulamayı memnuniyetle karşılamış; öğrenim becerilerinin iyileşmesine yardımcı olduğunu ifade etmiş ve klinik eğitimlerinin başından itibaren, diğer klinik branşlara da uygulanmasını önermişlerdir. ${ }^{38}$

Fakültelerde, öğrencilerin çoğu "klinik uygulama sürecinde eğitmen beni izler" kriterine katılmasa da, bu durum klinik eğitim ortamının yapısıyla ilgilidir. ${ }^{6}$ Öğrencilerimizin eğitmen gözetiminde çalışma, gereğinde yardım alma, hataları karşısında sabırlı davranma gibi davranışlara olan yanıtları; diğer çalışmalarla benzer şekilde ve düşük oranda katılım sergilemektedir. Eğitmen her klinik uygulama döneminde en az 8 öğrenciden sorumlu olduğunda, öğrencileri bire bir gözlemlemesi imkansızdır. Öğrenci sayısı yüksek olan eğitim ortamında, eğitmen: öğrenci oranı 1:6 olarak bildirilmiştir ${ }^{6}$; ancak klinik eğitimde ideal oranın 1:6 olduğuna dair sınırlı sayıda çalışma mevcuttur. Öğrenciler; daha yüksek eğitmen:öğrenci oranı varlığında, eğitimin daha etkili olacağını hissettiklerini ve klinik eğitimdeki eğitmen sayısının, klinik eğitmenlerin üst düzeyde klinik tecrübeye sahip olmasından daha fazla önem taşıdığını göstermişlerdir. ${ }^{6}$

Malezya, Malaya Üniversitesi'nde, klinik eğitmenin görevi ve katkısının; klinik uygulamalardaki çıraklık modeline göre öğrenciler tarafından değerlendirildiği bir araştırmada; genelde öğrenciler eğitmenleriyle ilgili olumlu algı sergilemişlerdir. ${ }^{6}$ Çalışmada; öğrencilerin klinik eğitim sürecinde eğitmenlerin davranışlarına ve klinik eğitim ortamına olan yanıtları çoğunlukla olumlu olmakla birlikte, katılım oranları \% 50'nin altında kalmıştır. Araştırmamızın bu yöndeki bulguları bu çalışmayı ${ }^{6}$ destekler niteliktedir; ancak katılım oranları bizim çalışmamızda nispeten daha yüksektir.

Öğrenciler; düşük klinik eğitmen: öğrenci oranının klinik eğitimin etkinliğini iyileştirdiğini fark etmişlerdir. ${ }^{6}$ Klinik eğitim ortamı öğrencilerden hem olumlu hem de olumsuz cevaplar almıştır. Klinik eğitmenlerinin öğrenci işleriyle ilgili olmadıklarını ve vakit ayırmadıklarını ve klinikte bulunmadıklarını ifade eden çalışmada ${ }^{6}$; öğrenciler; eğitim ortamını daha sert bir dille eleştirmiştir. Neredeyse her dental klinikte, eğitmenlerin eğitim sorumlulukları intiyacıyla klinikte bulunmaları gerekirken, klinikte olmamalarının genel bir problem olduğu belirtilmiştir. ${ }^{39} \mathrm{Bu}$ sonuçlar; fakültelerin bu problemi çözümleyip, öğrencilere daha elverişli bir eğitim ortamı oluşturmaları gerektiğini desteklemektedir.

Özellikle öğrenci sayısının fazla olduğu kliniklerde, eğitim gören öğrencilerin sayısına uygun eğitmen olmadığı düşünüldüğünde, öğrencilerin de kendi eğitim sorumluluklarını alarak, klinik seanslarına teorik ve ekipman olarak hazırlıklı gelmeleri, eğitmenlerini gözlemlemek için her fırsatı değerlendirmeleri, "kaşıkla beslenmeyi" beklememeleri gerekir. ${ }^{6}$

Öğrenciler ve klinik eğitim kadrosu arasında denge oluşturmak önemlidir. Olumlu eğitim ortamı oluşturmak, öğrencileri değerlendirmek, geri bildirim vermek ve kendini değerlendirmeyi desteklemenin (self-assesment) önemi birçok araştırmacı tarafından vurgulanmıştır. ${ }^{40-45}$

Klinik değerlendirmeler; öğrenciler için mücadeleyi gerektirebilir; çünkü bir taraftan, öğrenim süreci için tedavi ve hastaya yaklaşım önem taşırken, diğer taraftan öğrenci-eğitmen ilişkisine karmaşık bir durum katabilir. ${ }^{32}$ Hasta tedavisi üzerinden klinik öğrenim ve değerlendirme yapmak karmaşık bir durumdur; çünkü öğrenciler hastalar üzerinde geri dönüşümü olmayan uygulamalar yaparlar. Öğrenciler ve eğitmenler arasındaki tartışmaların çoğu hasta başında ve hastanın gözü önünde ortaya çıktığından, klinik öğretim ortamı öğrencilere eleştirel geri bildirim yapmak açısından zorluk yaratır. Ayrıca zaman kısıtlamaları nedeniyle değerlendirmeler göz ardı edilebilir. Eğitmenlerin; olumlu geri bildirimlerini hastanın duyacağı şekilde yapması, öğrenci-hasta iletişimine olumlu katkı sağlamakla birlikte, öğrenci özgüvenini de arttırır. ${ }^{46}$ Olumsuz geri bildirimler ise hastanın duyacağı şekilde yapılmamalıdır..40,47 Çalışmamızda eğitmenlerin öğrencilere doğru şekilde geri bildirim verme davranışlarına; öğrenciler ve hastaların katılımları olumlu olmakla birlikte yarıyı çok fazla geçmemiştir.

İyi klinik eğitmenlerin öğrencilerin klinikteki performanslarıyla ilgili yapıcı ve düzeltici geri bildirim vermesi ${ }^{37,47-49}$,teorik bilgiyi hasta tedavisiyle bir araya getirmesine yardımcı olması ve öğrencileri olumlu şekilde motive ederek, ilgili şekilde klinik öğretim sergilemesi beklenir. ${ }^{39,50,51}$ Öğrenciler için eğitmenin iyi bir rol model olması gerekir. ${ }^{52,53}$

Eğitim planlaması yaparken, klinik uygulama ve görevleri öğrencilerin seviyelerine, süreye ve şartlara uygun düzenlemek öğretim üyelerinin sorumluluğundadır. ${ }^{3}$ Çalışmamızda; klinik eğitimdeki uygulamaların düzeyi ve sayısı öğrenci bakış açısıyla sorgulanmış; klinik uygulamaların eğitim seviyesine ve çalışma sürelerine uygun olmasına yönelik öğrenci yanıtları; K+ ve TK düzeyleri toplamında sırasıyla \% 36 
ve \% 28 gibi düşük oranlarda kalmıştır. Öğrencilerin klinik ortamda öğrenme ve değerlendirmelerini etkileyen faktörler; klinik ortam şartları, zaman kısıtlamaları ve yeterlikleri için gereken vakaları bulma sorunu olarak sıralanmaktadır. ${ }^{54}$ Chambers ${ }^{50}$ ideal olarak öğrencilerin dental kliniklerdeki eğitime basit beceri seviyeleriyle başlamaları gerektiğini bildirmiştir. Klinik ortam; hem klinik uygulamalar hem de performans puanları açısından iyi bir öğrenme ortamı oluşturmalıdır.

Öğretimi değerlendiren öğrencilerin çoğu asistanlarının performansından memnun olmamış ${ }^{6}$ ve bulgularımı bu çalışmanın bulgularılla benzerlik göstermiştir. Öğrencilerin klinik eğitimi ve eğitmenlerini değerlendirdikleri çalışmalarda; Doğu Asyalı öğrencilerin eğitim sürecinde halinden memnun, kibar ve sessiz tavır sergiledikleri bildirilmiştir. ${ }^{28}$ Bazı durumlarda ve özellikle saygı duydukları kişilere karşı, öğrenciler gerçek düşüncelerini değerlendirmelere yansıtmayabilirler. ${ }^{6} \quad$ Ayrıca Asyalı öğrencilerin konuşmaya, soru sormaya ve mücadele etmeye daha az hazırlıklı oldukları da bildirilmiştir. ${ }^{55}$ Klinik eğitimde öğrenci-asistan dağılımı hazırlanırken, bir ön değerlendirme yapılıp, asistanların olumlu davranışlarını destekleyerek öğrencilerin öğrenme deneyimlerini iyileştirmek gerektiği vurgulanmıştır. ${ }^{56}$

Diş hekimliği; tıp fakültesi programları gibi müfredatın bilimsel yapısı nedeniyle daha çok teknik beceriler üzerinde yoğunlaşır. Mesleki beceriler ve uyum becerileri kazandırımasını içeren 21. yüzyıl müfredat inovasyon çalışmalarına öğretme ve öğrenme aktivitelerinin de entegre edilmesi öğrencilerin öğrenim çıktıları ve performanslarını kuşkusuz etkileyecektir. ${ }^{57}$ Klinik yeterlik; sosyal, kültürel ve politik ortamlara hassasiyeti gerektiren klinik uygulamalarda, iletişim becerileri, kritik düşünme, profesyonellik ve bilgi yönetimini kullanarak problemlerin tanımlanması ve çözümüyle gerçekleşir. ${ }^{58}$ Öğrencilerin basmakalıp kişiler olmasını önlemek için özellikle iletişim açısından uyum becerilerine (soft skills) sahip olmalarının önem kazandığı ileri sürülmüştür. Uyum becerileri; (1) iletişim, (2) düşünme ve problem çözme, (3) takım çalışması gücü, (4) hayat boyu öğrenme ve bilgi yönetimi, (5) girişimci, (6) etik, ahlak ve profesyonellik ve (7) liderlik becerileri olarak tanımlanmıştır. 59,60

Öğrencilerin başarısına katkı sağlayan ve eğitmenler tarafından algılanan kavramsal olmayan faktörlerin belirlenmesi ve bu faktörlerin akademik performans, klinik performans ve genel başarıya olan etkilerinin değerlendirilmesi amacıyla yapılan bir araştırmada ${ }^{61}$; 2015-2016 senelerinde Birleşmiş Milletler'de bir fakültedeki 184 nitelikli eğitmen içinden 43 tanesi çalışmada yer almıştır. Eğitmenler, öğrenci başarısına etki eden kavramsal olmayan faktörleri; iletişim/bireylerarası ilişki becerileri, öğrenme yaklaşımı, kişisel özellikler, profesyonellik ve teknik yetenekler olarak tanımlamış; akademik performans için hazır bulunuşluk, klinik performans için ise iletişim özelliğinin önemli olduğunu belirtmişlerdir. Çalışmada eğitmen, öğrenci ve hastaların iletişimleri de bu yönüyle kısmen sorgulanmıştır.

Illetişim becerisi; eleştirel düşünme, problem çözme, takım çalışması, liderlik ile profesyonel etik ve ahlak gibi diğer uyum becerilerinin gelişimi ile ilişkilidir; ancak hem öğretim hem de değerlendirme yönünden fakültelerde eşit derecede ele alınmamaktadır. ${ }^{62}$ Birçok çalışmada "öğrenci iletişim değerlendirme ölçeği" ve "hasta iletişim değerlendirme ölçeği" gibi iki değerlendirme aracı geliştirilmiştir. ${ }^{63,64}$ Öğrencilerin değerlendirilmesi genellikle hastaların bakış açısı yerine eğitmenler tarafından yapııı. Bazı çalışmalarda ise öğrencilerin iletişim becerilerini değerlendiren ölçek; hastalar ve yardımcı personel tarafından formüle edilmiştir. ${ }^{63,64}$ Saygllı ve ilgili davranma, bilgiyi paylaşma, takım üyeleriyle iletişim, konforu dikkate alma, profesyonel ilişki kurma ile randevu düzenleme ve takip şeklinde 7 bileşen incelenmiştir. Çalışmamızda öğrencilerin hastalarıyla olan iletişimleri ve hastalarını basitçe bilgilendirmeleri yönünden eğitmenlerinden yüksek oranda destek almadıkları görülmekle birlikte; hastaların öğrencilerle iletişimleriyle ilgili geri bildirimleri olumlu sonuçlanmıştır. Oysa ki; hasta merkezli fakültelerde, öğrencilerin iletişim becerilerinin geliştirilmesi önemlidir. 63,64

Dental eğitmenlerin hem çalıştıkları alanda uzman olmaları hem de iyi iletişim becerilerine sahip olmaları gerekir. ${ }^{65}$ Öğrencilere yapıcı geri bildirim verebilmek; etkili iletişim becerileri oluşturmayı sağlayan bir beceridir. ${ }^{66}$ Öğrenciler hastalarıyla pozitif iletişim kurmayı; klinikte eğitmenlerinin yaklaşım ve davranışlarını gözlemleyerek geliştirirler. ${ }^{32}$ Öğrenciler gizli müfredat üzerinden, rol modelleri sayesinde profesyonel davranışlar ve tutumlar geliştirirler. $\mathrm{Bu}$ nedenle de rol model oluşturma (gözetmenlik); klinik ortamında "öğretim" görevinin önemli bir parçasıdır. Eğitmenlerin, öğrencilerin eleştirel düşünme becerilerini geliştirmelerini desteklemeleri önemlidir. 67,68

Özellikle tıp eğitiminde standardize hastalar olarak bilinen hasta eğitimciler eğitim ortamına gerçeklik katarak, öğrenmeyi kolaylaştırır ve aptalca sorulan sorulara izin vererek hatalardan öğrenme yolunu açar. ${ }^{69}$ Hasta eğitmenler ve öğrenciler arasında dengeli bir güç oluşturmak öğrenmeyi mantıklı ve geçerli kılar. Öğrencilerin hastalarla olan iletişimlerini incelemek için farklı öğretme ve değerlendirme yöntemleri mevcuttur; bu amaçla hastalardan geribildirim alınması yönteminin hastalar ve öğrenciler 
tarafından nasıl algılandığı bir araştırmada incelenmiş; hem hastalar hem de öğrencilerin bu konuda çok istekli olduğu ve her iki taraf açısından faydalı olduğu bildirilmiştir. ${ }^{22}$ Fakülteler için müfredat geliştirmenin bir aşaması olan geri bildirim ve değerlendirmede, hastalar da önemli bir yer tutar. Çalışmamızda da klinik eğitimimizin önemli bir değeri olan hastalarımızdan öğrenci ve eğitmen davranışları yönünde geri bildirim alınmış ve hastalar çalışmaya memnuniyetle katılmıştır. Hastaların öğrenci davranışlarına yönelik ifadelere katıımı daha yüksek oranlarda gerçekleşmiş; öğrencilerin tedavilerinden memnun kaldıkları görülmüştür. Hastalar; eğitmenlerin de öğrencileri gözlemleme, uygulamalarını desteklemelerine yüksek oranda katılım sergilemekle birlikte; eğitmenlerin olumlu geri bildirimlerine ise düşük oranda tanık olduklarını; ancak hatalarına yönelik geri bildirimlerini duyacakları şekilde yaptıklarını ifade etmişlerdir.

Profesyonel eğitmen tutumları; tedavi kalitesi, dürüstlük, doğruluk, öğrencilere olumlu yaklaşım, öğrenciye saygı, diğer meslektaşlarla olumlu etkileşim, öğretim, eğitim, duyarlık ve destek için hevesli olma, iyi rol model olma, uzmanlığın içerik ve sürecine bağlanmıştır ${ }^{70-72}$; ancak profesyonelliğin tanımı tartışmalıdır. ${ }^{73,74}$ Profesyonelliği bütüncül anlamda görerek "akıl, eller ve kalp" yönüyle açıklamak faydalı olabilir. ${ }^{75}$ Eğitmenin "doğru işler yapması" (akıl) gerekir. Öğretim ve öğrencinin öğrenimini desteklemek için gerekli olan becerileri sergilemek için "işleri doğru yapması" (eller) gerekir. Son olarak, öğretme mesleğinin gereği olan davranışlara sahip olması için "doğru insan olması" (kalp) gerekir. Eğitim profesyonelliğinin mesleki tutumlardan farklı bir birikim olarak görülmemesi; hatta eğitmenlerin çekirdek özellikleri arasında yer alması beklenir. ${ }^{76}$

Fakültelerde öğretim üyesi asistanlarının lisans klinik eğitiminde klinik eğitmen olarak yer alması; çok sayıda vaka üzerinde tedavi planlaması, komplikasyonların çözüme ulaştırılması gibi önemli kazanımlara ulaşmalarını da sağlar. Çalışmamıza katılan klinik eğitmenler de lisans klinik eğitiminde bulunma süreçlerinde benzer kazanımlar elde ettiklerini, ifadelere verdikleri yüksek oranda katılımla göstermişler; klinik eğitimde yer alarak akademik anlamda ve öğrencilerle iletişim kurmaktan mutlu olduklarını, klinik ve karar verme becerilerini geliştirdiklerini, tedavi uygulamalarındaki hatalarını gördüklerini belirtmişlerdir.

Eğitmen olmak bir süreci gerektirir. Klinikte eğitim verecek olan eğitmen öncelikle öğretilecek klinik beceride uzman bir hizmet sunucu olmalıdır. Öğretim üyesi yardımcılarının da, eğitmen olmadan önce mesleki becerilerini kazanarak beceride uzmanlaşması, ustalık kazanması gerekir. Nitekim, çalışmamıza katılan klinik eğitmenler de "deneyim kazanıp eğitici olarak görev alsaydım diye düşünürüm” ifadesine yüksek oranda katılım göstermişlerdir. Ayrıca verdikleri yanıtlardan, klinik eğitim ortamında yazılı talimatlar olduğunda, güvenle çalışacakları da anlaşılmaktadır.

Eskiden mesleki beceriyi kazanan kişinin iyi bir eğitmen olacağı düşünülürdü; ancak günümüzde uzmanlık konusunu başkalarına etkili bir şekilde aktarabilmek için "Eğiticinin Eğitimi" ve "Eğitim Becerileri" gibi eğitimlerin zorunlu hale gelmesi kaçınılmazdır. ${ }^{77}$ Eğiticinin eğitimi programlarında öğrenme psikolojisi, öğretme teknikleri, ders hazırlama yöntemleri, 21. yüzyıl uyum becerileri, yeterlikler, ölçme ve değerlendirme gibi konulara yer verilmektedir. Temelinde yetişkin öğrenme prensipleri yatan kurslar ile yetiştiricilik, hümanistik eğitim teknikleri ve klinik işlemin uygulanmasında standart yaklaşım kazanılmış olur. Ayrıca, öğrencilerin veya katılımcıların performansını değerlendirmede yeterliğe dayalı öğrenim ve değerlendirme ölçekleri ve kontrol listelerini hazırlama ve kullanma, yeni bilgiyi aktarmada etkili sunum yapabilmek için küçük grup dersleri, gösterim, oyunlaştırma, rol yapma, vaka çalışmaları, beyin fırtınaları ve grup tartışmalarını da öğrenirler. Eğitmen adaylarının klinik eğitime katılmadan önce uzman eğitmenin yanında klinik eğitmen olarak çalışarak deneyim kazanması da önemlidir. ${ }^{77}$

Çoğu klinisyen başkalarını eğitmektense mesleklerini icra etmeyi tercih eder. Hatalarını kabul edebilen, öğrencilerle iyi iletişim kurabilen ve onları yüreklendiren kişiler iyi eğitmen olabilirler. Öğrencilere, kendilerinin en iyi olduğunu, kendi seviyelerine ulaşmanın zor olduğunu ispatlamaya çalışarak, öğrencilerin istek ve özgüvenlerini yıkan kişiler eğitmen olamazlar. Eğitmenlerin öğretime hevesli olmaları etkili eğitimin önemli bir bileşeni olarak görülmektedir. ${ }^{53,78}$ Eğitimle gerçek anlamda ilgilenen bir sağlık çalışanı, eğitim becerilerini öğrenmek ve uygulamak için gereken zamanı ayırmaya istekli olmalıdır. Klinik eğitmenlerin dakikliği, tutarlılığı, klinikteki varlığı, anlayışlı ve saygılı olmasının önemine dikkat çekilmiştir. ${ }^{32}$ Dakiklik ve klinikte bulunmak; öğrencilerin bir sonraki aşamaya geçmeden önce vakit kaybetmeden tedavide ilerlemesi için klinik eğitmenlerini bekleme ihtiyacı olmaması açısından önemlidir. Bu durum; özellikle tek seanslık klinik uygulamalarda, çalışmanın kalitesini direkt olarak etkileyebilir. İyi klinik eğitmenlerin; motive, coşkulu, merhametli, ilgili, öğrencilerine karşı duyarlı ve etkin davranış sergiledikleri bilinmektedir. ${ }^{50}$ İdeal klinik eğitim ortamında, öğrencilerin kendiliğinden aktif şekilde katılım sağladığı düşünülür ve öğrencinin mesleki davranışları, düşünme ve tutumlarının geliştirilmesinde daha çok klinik eğitmenlerin etkili oldukları düşünülür. ${ }^{79}$ 
Sonraki çalışmalarda diş hekimliği öğrencilerinin klinik eğitimde uyum becerilerini ne şekilde uyguladıklarını değerlendirerek, inmal edilen uyum becerileri ile ilgili farkındalık kazandırmak ve öğretimdeki açıkları kapatmak üzere planlama yapmak faydalı olabilir. Ayrıca, klinik eğitimdeki öğretim yaklaşımları; nedenleriyle ilişkilendirilerek de değerlendirilebilir. Öğretimi değerlendiren araştırma planlamalarında hedef; öğrencilerde tam öğrenme (mastery learning) sağlamak; amaç ise faklı koşullar altındaki eğitim ortamlarında yaşanan sorunlara çözüm üretmektir.

\section{SONUÇ}

Çalışmamız sonuçları; klinik eğitim ortamının öğrenciler ve eğitmenler için zorlu ve mücadele gerektiren özellikte olduğunu bir kez daha göstermiş̧ir. Öğrenciler; klinik eğitimde beceri kazanma hevesinde olup, kendi sorumluluklarını belirli oranda yerine getirdiklerini belirtirken, eğitmenler ve eğitim koşullarından beklentilerini açıkça dile getirmişlerdir. Klinik eğitmenler ise lisans klinik eğitim ortamında yer almaktan akademik olarak memnun olmakla birlikte, eğitimci olmadan önce deneyim kazanma intiyaçları olduğunu ve klinik eğitimde gerek uygulama ve gerekse değerlendirme rehberleriyle daha güvenle çalışacaklarını bildirmişlerdir. Hastalar; klinik eğitim ortamının vazgeçilmez üyeleridir; gerek tedavilerini gerçekleştiren öğrenciler ve gerekse eğitmenlerden memnuniyetlerini ifade etmişler; eğitmenlerin gözetim ve değerlendirme yaparken hümanistik eğitim davranışları olarak bilinen önerilere katıımlarını açıkça belirtmişlerdir. Klinik eğitimdeki eğitmen davranışları açısından, öğrenciler ve klinik eğitmenler arasında her ne kadar bazı tutarsızlıklar olsa da, hastaların da değerlendirmeleri dikkate alındığında, yaşanan sorunlar net olarak görülmüştür.

\section{Teşekkür}

Çalışmadaki katkılarından dolayı, 2017-2018 araşıırma ve sunum teknikleri dersindeki aşağıda isimleri geçen öğrencilerime teşekkür ederim.

Asu Nur Sandıkçı, Betül Karbölen, Beyza Talu, Buket Gümüştekin, Çağrı Pekyürek, Didem Erdal, Elif Polat, Ezgi Demirhan, Ezgi Kahraman, Gizem Gökçen, Gökhan Hilmi Üner, İrem Şafak, Merve Buse Kultaş, Ramazan Ağırağaç, Seda Ziyaretli, Sevda Shakeri, Sevinç Sevgi, Yusuf Er. 


\section{KAYNAKLAR}

1. Padmapriya T. The perspectives and perceptions of dental education in the West and an overview of dental education in India. J Educ Ethics Dent 2015; 5: 41-6.

2. American Dental Education Association. ADEA competencies for the new general dentist. J Dent Educ 2017; 81: 844-7.

3. Albino JE, Young SK, Neumann LM, Kramer GA, Andrieu SC, Henson L, et al. Assessing dental students' competence: best practice recommendations in the performance assessment literature and investigation of current practices in predoctoral dental education. J Dent Educ 2008; 72: 1405-35.

4. Hendricson WD, Kleffner JH. Curricular and instructional implications of competency-based dental education. J Dent Educ 1998; 62: 183-96.

5. Gerzina TM, McLean T, Fairley J. Dental clinical teaching: perceptions of students and teachers. J Dent Educ 2005; 69: 1377-84.

6. Shoaib LA, Safii SH, Naimie Z, Ahmad NA, Sukumaran $P$, Yunus RM. Dental students' perceptions on the contribution and impact role of a clinical teacher. Eur $\mathrm{J}$ Dent Educ 2018; 22: 26-34.

7. Anderson VR, Rich AM, Seymour GJ. Undergraduate dental education in New Zealand: 2007-2009 final-year student feedback on clinical learning environments. NZ Dent J 2011; 107: 85-90.

8. Khoo EM, Teoh KS. The effective teacher. Malays Fam Physician. 2007; 2: 123-4.

9. Carnell E. Conceptions of effective teaching in higher education: extending the boundaries. Teach High Educ 2007; 12: 25-40.

10.Graffam B. Deriving better questions: creating better clinical instruction. Clin Teach 2008; 5: 98-102.

11.Collins A, Brown JS, Newman SE. Cognitive apprenticeship: teaching the crafts of reading, writing, and mathematics. In: Resnick LB ed. Knowing, learning, and instruction: Essays in Honor of Robert Glaser. Hillsdale, New Jersey: Lawrence Erlbaum Associates, Inc; 1989: 453-94.

12.Stalmeijer RE, Dolmans DHJM, Wolfhagen IHAP, Muijtjens AMM, Scherpbier AJJA. The development of an instrument for evaluating clinical teachers: involving stakeholders to determine content validity. Med Teach 2008; 30: 272-7.

13.Grillo AC, Murdoch-Kinch CA, Ramaswamy V, Inglehart MR. Student evaluations of teaching: dental and dental hygiene students' and faculty members' perspectives. J Dent Educ 2016; 80: 439-51.

14. Marsh H. Students' evaluation of university teaching: research findings, methodological issues, and direction for future research. Int J Educ Res 1987; 11: 253-388.

15. Yao Y, Grady M. How do faculty make formative use of student evaluation feedback? A multiple case study. J Pers Eval Educ 2005; 18: 107-26.
16. Frick TW, Chadha R, Watson C, Zlatkovska E. Improving course evaluations to improve instruction and complex learning in higher education. Educ Tech Res Dev 2010; 58: 115-36.

17. Youssef LS. Using student reflections in the formative evaluation of instruction: a courseintegrated approach. Refl Pract 2012; 13: 237-54.

18.Dommeyer CJ, Baum P, Hanna RW, Chapman KS. Gathering faculty teaching evaluations by in-class and online surveys: their effects on response rates and evaluations. Assess Eval Higher Educ 2004; 29: 611-25.

19. Crews TB, Curtis DF. Online course evaluations: faculty perspective and strategies for improved response rates. Assess Eval Higher Educ 2011; 36: 865-78.

20. Hmieleski KM, Champagne MV. Plugging in to course evaluation. The Technology Source, Sept./Oct. 2000. At: technologysource.org/ article/ plugging_in_to_course_evaluation/. Accessed 21 March 2015.

21. Morrison R. A comparison of online versus traditional student end-of-course critiques in resident courses. Assess Eval Higher Educ 2011; 36: 627-41.

22. Coelho C, Pooler J, Lloyd H. Using patients as educators for communication skills: Exploring dental students' and patients' views. Eur J Dent Educ 2018; 22: 291-9.

23.Jha V, Quinton ND, Bekker HL, Roberts TE. What educators and students really think about using patients as teachers in medical education: a qualitative study. Med Educ 2009; 43: 449-56.

24.Walsh SE, Singleton JA, Worth CT, Krugler J, Moore R, Wesleyet GC, et al. Tobacco cessation counseling training with standardized patients. J Dent Educ 2007; 71: 1171-8.

25.Edström K. Doing course evaluation as if learning matters most. Higher Educ Res Dev 2009; 27: 95106.

26. Adams MD, Umbach PD. Nonresponse and online student evaluations of teaching: understanding the influence of salience, fatigue, and academic environments. Res Higher Educ 2012; 53: 576-91.

27. Huybers T. Student evaluation of teaching: the use of best-worst scaling. Assess Eval Higher Educ 2014; 39: 496-513.

28.Wong R, Niu W. Cultural difference in stereotype perceptions and performances in nonverbal deductive rand creativity. J Creat Behav 2013; 47: 41-59.

29. Mullins G, Wetherell J, Robbe I. Learning in the clinical environment. In: Sweet J, Huttly S, Taylor I, eds. Effective learning and teaching in medical, dental and veterinary education. London: Kogan Page 2003:164-79. 
30.McMillan W. Making the most of teaching at the chairside. Eur J Dent Educ 2011; 15: 63-8.

31. Eriksen HM, Bergdahl J, Bergdahl M. A patientcentered approach to teaching and learning in dental student clinical practice. Eur J Dent Educ 2008; 12: 170-5.

32.Fugill M. Teaching and learning in dental student clinical practice. Eur J Dent Educ 2005; 9: 131-6.

33. Srinivasan M, Li ST, Meyers FJ, Pratt DD, Collins JB, Braddock $\mathrm{C}$, et al. "Teaching as a competency": competencies for medical educators. Acad Med 2011; 86: 1211-20.

34. Harden RM, Crosby J. Amee guide no 20: the good teacher is more than a lecturer - the twelve roles of the teacher. Med Teach 2000; 22: 334-47.

35. COPDEND. Copdend standards for dental educators. Manchester: The UK Committee of Postgraduate Dental Deans and Directors, 2013.

36. Azer SA. Challenges facing pbl tutors: 12 tips for successful group facilitation. Med Teach 2005; 27 : 676-81.

37. Cowpe J, Plasschaert A, Harzer W, Vinkka-Puhakka $H$, Walmsley AD. Profile and competences for the graduating european dentist -update 2009. Eur J Dent Educ 2010; 14: 193-202.

38. Singh G, Kaur R, Mahajan A, Thomas AM, Singh T. Piloting direct observation of procedural skills in dental education in India. Int J Appl Basic Med Res 2017; 7: 239-42.

39.Polyzois I, McLoughlin J, Kelly A, Claffey N. Clinical teaching in restorative dentistry and the variation between students' and supervisors' perceptions of its effectiveness. Eur J Dent Educ 2010; 14: 92-8.

40. Branch WT Jr, Paranjape A. Feedback and reflection: teaching methods for clinical settings. Acad Med 2002; 77: 1185-8.

41. Irby D, Bowen JL. Time-efficient strategies for learning and performance. Clin Teach 2004; 1: 23-8.

42. Larsen DP, Butler AC, Roediger HL 3rd. Testenhanced learning in medical education. Med Educ 2008; 42: 959-66.

43.Larsen DP, Butler AC, Roediger HL 3rd. Repeated testing improves long-term retention relative to repeated study: a randomised controlled trial. Med Educ 2009; 43: 1174-81.

44. Kiehl C, Simmenroth-Nayda A, Goerlich Y, Entwistle A, Schiekirka S, Ghadimi BM, et al. Standardized and quality-assured video-recorded examination in undergraduate education: informed consent prior to surgery. J Surg Res 2014; 191: 64-73.

45. Landes CA, Hoefer S, Schuebel F, Ballon A, Teiler A, Tran $A$, et al. Long-term prospective teaching activity of practical skills training and a first OSCE in cranio maxillofacial surgery for dental students. J Craniomaxillofac Surg 2014; 42: 97-104.
46. Curtis DA, O'Sullivan P. Does trainee confidence influence feedback? Med Educ 2014; 48: 943-6.

47. Boehler ML, Rogers DA, Schwind CJ, Mayforth R, Quin J, Williams RG, et al. An investigation of medical student reactions to feedback: a randomized controlled trial. Med Educ 2006; 40: 746-9.

48.Sandars J. The use of reflection in medical education: AMEE guide no. 44. Med Teach 2009; 31: 685-95.

49. Kaufman DM. Applying educational theory in practice. BMJ 2003; 326: 213-6.

50.Chambers DW, Geissberger M, Leknius C. Association amongst factors thought to be important by instructors in dental education and perceived effectiveness of these instructors by students. Eur J Dent Educ 2004; 8: 147-51.

51. Henzi D, Davis E, Jasinevicius R, Hendricson W, Cintron L, Isaacs M. Appraisal of the dental school learning environment: the students' view. J Dent Educ 2005; 69: 1137-47.

52.Duvivier RJ, Van Dalen J, van Der Vleuten CPM, Scherpbier AJJA. Teacher perceptions of desired qualities, competencies and strategies for clinical skills teachers. Med Teach 2009; 31: 634-41.

53.Schönwetter DJ, Lavigne S, Mazurat R, Nazarko O. Students' perceptions of effective classroom and clinical teaching in dental and dental hygiene education. J Dent Educ 2006; 70: 624-35.

54.Bertoli E, Lawson KP, Bishop SS. Dental Students' Skills Assessments: Comparisons of daily clinical grades and clinical and laboratory assessments. J Dent Educ 2018; 82: 417-23.

55.Frambach JM, Driessen EW, Beh P, van der Vleuten CPM. Quiet or questioning? Students' discussion behaviors in student-centered education across cultures. Stud High Educ 2014; 39: 1001-21.

56. Abu Kasim NH, Abu Kassim NL, Razak AAA, Abdullah H, Bindal P, Che' Abdul Aziz ZA, et al. Pairing as an instructional strategy to promote soft skills amongst clinical dental students. Eur J Dent Educ 2014; 18: 51-7.

57. Kereluik K, Mishra P, Fahnoe C, Terry L. What knowledge is of most worth: teacher knowledge for 21st century learning. J Digital Learn Teach Educ 2013; 29: 127-40.

58. Khatami S, Macentee MI. Evolution of clinical reasoning in dental education. Dent Educ 2011; 75: 321-8.

59.Gonzalez MAG, Abu Kasim NH, Naimie Z. Soft skills and dental education. European $\mathrm{J}$ Dent Educ 2013; 17: 73-82. 
60. Quieng MC, Lim PP, Lucas MRD. 21st century-based soft skills: spotlight on non-cognitive skills in a cognitive-laden dentistry program. European $\mathrm{J}$ Contemp Educ 2015; 11: 71-81.

61. Virtue SM, Pendergast L, Tellez M, Waldron E, Ismail A. Identifying noncognitive skills that contribute to dental students' success: dental faculty perspectives. J Dent Educ 2017; 81: 300-9.

62. Yoshida T, Milgrom P, Coldwell S. How do US and Canadian dental schools teach interpersonal communication skills? J Dent Educ 2002; 66: 1281-8.

63.Sch€onwetter DJ, Wener ME, Mazurat N. Determining the validity and reliability of clinical communication assessment tools for dental patients and students. J Dent Educ 2012; 76: 1276-90.

64.Sch€onwetter DJ, Wener ME, Mazurat N, Yakiwchuk B. Exploring the predictive ability of two new complementary instruments for assessing effective therapeutic communication skills of dental and dental hygiene students. J Dent Educ 2012; 76: 1291-310.

65.Prideaux D, Alexander H, Bower A, Dacre J, Haist S, Jolly $B$, et al. Clinical teaching: maintaining an educational role for doctors in the new health care environment. Med Educ 2000; 34: 820-6.

66. Ramani S, Leinster S. Amee guide no. 34: teaching in the clinical environment. Med Teach 2008; 30: 347-64.

67 . Hand JS. Identification of competencies for effective dental faculty. J Dent Educ 2006; 70: 937-47.

68. Bligh J, Brice J. Further insights into the roles of the medical educator: the importance of scholarly management. Acad Med 2009; 84: 1161-5.

69. Henriksen A-H, Ringsted C. Learning from patients: students' perceptions of patient-instructors. Med Educ 2011; 45: 913-9.

70. Hesketh EA, Bagnall G, Buckley EG, Friedman M, Goodall E, Harden RM, et al. A framework for developing excellence as a clinical educator. Med Educ 2001; 35: 555-64.

71.Elzubeir MA, Rizk DE. Identifying characteristics that students, interns and residents look for in their role models. Med Educ 2001; 35: 272-7.

72. Paukert JL, Richards BF. How medical students and residents describe the roles and characteristics of their influential clinical teachers. Acad Med 2000; 75: 843-5.

73. Bostock S, Baume D. Professions and professionalism in teaching and development. In: Baume D, Popovic C, eds. Advancing practice in academic development. Abingdon: Routledge, 2016; 32-50.

74. Seery A. Ethics and professionalism in teaching. Stud Irish Q Rev 2008; 97: 183-92.

75. Easton F. Educating the whole child, "head, heart, and hands": learning from the waldorf experience. Theory into Practice 1997; 36: 87-94.

76. Singh S, Pai DR, Sinha NK, Kaur A, Soe HH, Barua A. Qualities of an effective teacher: what do medical teachers think? BMC Med Educ 2013; 13: 128.
77.Chuenjitwongsa $S$, Oliver RG, Bullock $A D$. Competence, competency-based education, and undergraduate dental education: a discussion paper. Eur J Dent Educ 2016; 22: 1-8.

78. Divaris K, Barlow PJ, Chendea SA, Cheong WS, Dounis A, Dragan IF, et al. The academic environment: the students' perspective. Eur J Dent Educ 2008; 12: 120-30.

79. Spencer John. ABC of learning and teaching in medicine learning and teaching in the clinical environment. BMJ 2003; 326: 1.

Yazışma Adresi:

Prof. Dr. Funda AKALTAN

Ankara Üniversitesi

Diş Hekimliği Fakültesi

Protetik Diş Tedavisi AD

06560, Beşevler, Ankara

Tel : +90 5323444755

E-mail: akaltanfunda@gmail.com 